\title{
Crystal-chemistry of micas belonging to the yangzhumingite-fluorophlogopite and phlogopite-fluorophlogopite series from the Apuan Alps (northern Tuscany, Italy)
}

\author{
Maria Lacalamita $^{1} \cdot$ Emanuela Schingaro $^{1} \cdot$ Ernesto Mesto $^{1} \cdot$ Federica Zaccarini $^{2} \cdot$ Cristian Biagioni $^{3}$
}

Received: 7 August 2020 / Accepted: 7 October 2020 / Published online: 19 November 2020

(c) The Author(s) 2020

\begin{abstract}
The present work reports the crystal-chemical characterization of micas from the Monte Arsiccio and Buca della Vena mines (Apuan Alps, Italy) through electron microprobe analysis, single-crystal X-ray diffraction, and Raman spectroscopy. The sample from the Monte Arsiccio mine can be classified as an intermediate member of the yangzhumingite-fluorophlogopite series, with average crystal-chemical formula $\left(\mathrm{K}_{0.85} \mathrm{Na}_{0.01} \mathrm{Ba}_{0.09}\right)_{\Sigma=0.95}\left(\mathrm{Mg}_{2.11} \mathrm{Fe}^{2+}{ }_{0.23} \mathrm{Fe}^{3+}{ }_{0.11} \mathrm{Cr}^{3+}{ }_{0.01} \mathrm{Al}_{0.20} \mathrm{Ti}_{0.04} \square_{0.30}\right)_{\Sigma=3.00}\left(\mathrm{Si}_{3.20} \mathrm{Al}_{0.80}\right)_{\Sigma=4.00} \mathrm{O}_{10.00} \mathrm{~F}_{1.90} \mathrm{Cl}_{0.02}(\mathrm{OH})_{0.08}$. Unitcell parameters are $a \sim 5.30, b \sim 9.18, c \sim 10.14 \AA, \beta \sim 100.12^{\circ}, V \sim 486.22 \AA^{3}$, corresponding to the $1 M$ polytype. Structure refinements, performed in $C 2 / \mathrm{m}$ space group, converged to $R_{1}=3.54$ and $4.46 \%$ and provided Mg plus Fe occupancy in the range $86-94 \%$ for the octahedral $M 1$ and $M 2$ sites. Raman spectroscopy shows very weak bands in the OH stretching region at 3690 and $3580 \mathrm{~cm}^{-1}$. The sample from the Buca della Vena mine has been identified as an $(\mathrm{OH})$-rich fluorophlogopite, with average crystal-chemical formula $\left(\mathrm{K}_{0.84} \mathrm{Na}_{0.02} \mathrm{Ca}_{0.01}\right)_{\Sigma=0.87}\left(\mathrm{Mg}_{2.12} \mathrm{Fe}^{2+}{ }_{0.55} \mathrm{Fe}^{3+}{ }_{0.10} \mathrm{Al}_{0.18} \square_{0.05}\right)_{\Sigma=3.00}\left(\mathrm{Si}_{2.99} \mathrm{Al}_{1.01}\right)_{\Sigma=4.00} \mathrm{O}_{10.00} \mathrm{~F}_{1.02} \mathrm{Cl}_{0.09}(\mathrm{OH})$ 0.89. Its unit-cell parameters are $a \sim 5.33, b \sim 9.22, c \sim 10.23 \AA, \beta \sim 100.09^{\circ}, V \sim 494.39 \AA^{3}$. Structure refinements gave good $R_{1}$ values (3.27 and 4.37\%) and revealed octahedral occupancy of $82-84 \% \mathrm{Mg}$ and $16-18 \% \mathrm{Fe}$. Strong Raman signals at $~ 3702 \mathrm{~cm}^{-1}$ and $3595 \mathrm{~cm}^{-1}$ were observed in the $\mathrm{OH}$ stretching region. The findings allow to better understand not only the mineralogy of the Apuan Alps but, more generally, the crystal chemical details of intermediate dioctahedral-trioctahedral mica belonging to the yanzhumingite-fluorophlogopite series.
\end{abstract}

Keywords Yangzhumingite-fluorophlogopite series $\cdot$ Phlogopite-fluorophlogopite series $\cdot$ Crystal-chemistry $\cdot$ Monte Arsiccio $\cdot$ Buca della Vena $\cdot$ Apuan Alps

Electronic supplementary material The online version of this article (https://doi.org/10.1007/s00269-020-01118-2) contains supplementary material, which is available to authorized users.

Maria Lacalamita

maria.lacalamita@uniba.it

1 Dipartimento di Scienze della Terra e Geoambientali, Università degli Studi di Bari ALDO MORO, via Orabona 4, 70125 Bari, Italy

2 Department of Applied Geological Sciences and Geophysics, University of Leoben, Peter Tunner Str. 5, 8700 Leoben, Austria

3 Dipartimento di Scienze della Terra, Università di Pisa, via Santa Maria 53, 56126 Pisa, Italy

\section{Introduction}

Yangzhumingite, ideally $\mathrm{KMg}_{2.5} \mathrm{Si}_{4} \mathrm{O}_{10} \mathrm{~F}_{2}$, is a tetrasilicic potassium fluor-mica found in few localities worldwide. The first natural occurrence of this very rare mineral was reported in a metamorphosed carbonate rock from Bayan Obo, Inner Mongolia, China (Miyawaki et al. 2011). The Bayan Obo yangzhumingite has crystal-chemical formula $\left(\mathrm{K}_{0.70} \mathrm{Li}_{0.30} \mathrm{Na}_{0.01}\right)_{\Sigma=1.01}$ $\left(\mathrm{Mg}_{2.48} \mathrm{Fe}_{0.06}\right)_{\Sigma=2.54}\left(\mathrm{Si}_{3.96} \mathrm{Al}_{0.03}\right)_{\Sigma=3.99} \mathrm{O}_{10} \mathrm{~F}_{1.92}(\mathrm{OH})_{0.08}$ and unit-cell parameters, derived from $\mathrm{X}$-ray powder diffraction data, $a=5.249(4), b=9.095(5), c=10.142(5)$ $\AA, \beta=99.96(6)^{\circ}, V=476.9(5) \AA^{3}$ (Miyawaki et al. 2011). Yangzhumingite was also identified in a lamproitic dyke at the Kvaløya Island, North Norway (Kullerud et al. 
2011; Schingaro et al. 2014). The crystal-chemical formula of this second occurrence is $\left(\mathrm{K}_{0.98} \mathrm{Na}_{0.03}\right)_{\Sigma=1.01}$ $\left(\mathrm{Mg}_{2.35} \mathrm{Fe}^{2+}{ }_{0.23} \mathrm{Cr}_{0.01} \mathrm{Ti}_{0.02} \mathrm{Ni}_{0.01}\right)_{\Sigma=2.62}\left(\mathrm{Si}_{3.66} \mathrm{Al}_{0.34}\right)$ $\Sigma=4.00 \mathrm{O}_{10.00} \mathrm{~F}_{1.16}(\mathrm{OH})_{0.84}$; its crystal-chemistry was investigated by Schingaro et al. (2014) through single-crystal X-ray diffraction $(a=5.2677(3), b=9.1208(5), c=10.1652(6) \AA$, $\beta=100.010(4)^{\circ}, V=480.96(5) \AA^{3}$, s.g. $\left.C 2 / m\right)$. Recently, another finding of yangzhumingite was reported in fumarole sublimates of the Tolbachik volcano, Kamchatka, Russia (Shchipalkina et al. 2020), with empirical formulae $\left(\mathrm{K}_{0.86} \mathrm{Na}_{0.17}\right)_{\Sigma=1.03}\left(\mathrm{Mg}_{2.49} \mathrm{Cu}_{0.08} \mathrm{Ti}_{0.02}\right)_{\Sigma=2.59}$ $\left(\mathrm{Si}_{3.76} \mathrm{Fe}^{3+}{ }_{0.11} \mathrm{Al}_{0.09} \mathrm{Zn}_{0.04} \mathrm{As}^{5+}{ }_{0.02}\right)_{\Sigma=4.02} \mathrm{O}_{10} \mathrm{~F}_{1.93}$ and $\left(\mathrm{K}_{0.72} \mathrm{Na}_{0.03}\right)_{\Sigma=0.75}\left(\mathrm{Mg}_{2.74} \mathrm{Cu}_{0.02} \mathrm{Mn}_{0.01}\right)_{\Sigma=2.77}$ $\left(\mathrm{Si}_{3.76} \mathrm{Al}_{0.19} \mathrm{Fe}^{3+}{ }_{0.04}\right)_{\Sigma=3.99} \mathrm{O}_{10} \mathrm{~F}_{1.97}$. Unit-cell parameters are $a=5.351(21), b=9.244(24), c=10.20(3) \AA$ and $\beta=100.4(3)^{\circ}, V=496.2(4) \AA^{3}$.

Tetrasilicic fluor-mica of compositions $\mathrm{KMg}_{2.5} \mathrm{Si}_{4} \mathrm{O}_{10} \mathrm{~F}_{2}$ and $\mathrm{KMg}_{2.75}\left(\mathrm{Si}_{3.5} \mathrm{Al}_{0.5}\right) \mathrm{O}_{10} \mathrm{~F}_{2}$ were synthetized by Toraya et al. (1976, 1978). Seifert and Schreyer (1971) evidenced that synthetic tetrasilicic potassium mica $\mathrm{KMg}_{2.5} \mathrm{Si}_{4} \mathrm{O}_{10}(\mathrm{OH})_{2}$ forms ternary solid solution with phlogopite, $\mathrm{KMg}_{3}\left(\mathrm{Si}_{3} \mathrm{Al}\right) \mathrm{O}_{10}(\mathrm{OH})_{2}$, and an hypothetical mica of formula $\mathrm{KMg}_{3}\left(\mathrm{Si}_{3.5} \mathrm{Al}_{0.5}\right) \mathrm{O}_{10}(\mathrm{OH})_{2}$. Similarly, a series between yangzhumingite and fluorophlogopite, ideally $\mathrm{KMg}_{3}\left(\mathrm{Si}_{3} \mathrm{Al}\right) \mathrm{O}_{10} \mathrm{~F}_{2}$, could exist. The crystal-chemical features of fluorophlogopite were described in several studies also in relation to the $(\mathrm{OH})$-end member phlogopite (e.g. Gianfagna et al. 2007 and references therein; Schingaro et al. 2011; Balassone et al. 2013; Lacalamita et al. 2017). In particular, Gianfagna et al. (2007) showed that fluorophlogopite from Biancavilla (Sicily) crystallizes in the $1 M$ polytype $(C 2 / m$ s.g.) and exhibits a more compact structure than that of phlogopite. For instance, fluorophlogopite has a $c$ cell parameter significantly shorter (10.1437(8) $\AA$, Gianfagna et al. 2007) than that of phlogopite (e.g., 10.310(6) $\AA$, Redhammer and Roth 2002); the value of the interlayer spacing $(\sim 3.322 \AA$, Gianfagna et al. 2007) is also shorter than that of phlogopite (e.g., $3.487 \AA$, Redhammer and Roth 2002). This difference is explained by the change of the $\mathrm{H}^{+}-\mathrm{K}^{+}$Coulombic repulsion into $\mathrm{F}^{-}-\mathrm{K}^{+}$attraction when the $(\mathrm{OH})^{-}-\mathrm{F}^{-}$substitution occurs. Lacalamita et al. (2017) evidenced that the $(\mathrm{OH})^{-}-\mathrm{F}^{-}$substitution causes structural distortions, mainly along the direction close to the $\mathrm{K}-\mathrm{O}(4)$ bond, similar to those observed in oxyphlogopite or in phlogopite affected by ( $\left.\mathrm{Al}, \mathrm{Fe}^{3+}, \mathrm{Cr}\right)$-oxy [ ${ }^{\mathrm{VI}} \mathrm{M}^{2+}+(\mathrm{OH})^{-} \leftrightarrow{ }^{\mathrm{VI}} \mathrm{M}^{3+}+\mathrm{O}^{2-}+1 / 2$ $\mathrm{H}_{2} \uparrow$ ] or Ti-oxy [ $\left.{ }^{\mathrm{VI}} \mathrm{M}^{2+}+2(\mathrm{OH})^{-} \leftrightarrow{ }^{\mathrm{VI}} \mathrm{Ti}^{4+}+2 \mathrm{O}^{2-}+\mathrm{H}_{2} \uparrow\right]$ substitutions.

New findings of potassium- and fluorine-bearing micas, belonging to the yangzhumingite-fluorophlogopite and phlogopite-fluorophlogopite series, were identified in the pyrite \pm baryte \pm iron oxide ore deposits of Monte Arsiccio and Buca della Vena, Apuan Alps, Tuscany (Italy). These specimen were characterized through a multi-technique approach that includes electron microprobe (EMP) analysis, single-crystal X-ray diffraction (SCXRD) and Raman spectroscopy. It is noteworthy that notwithstanding more than 150 years of mineralogical studies on the mineralogy of the Apuan Alps, no accurate crystal-chemical studies on mica group minerals have been previously reported. For this reason, this contribution has a two-fold aim: to contribute to the knowledge of the mica mineralogy from this sector of the Northern Apennines; to improve our understanding of the intermediate dioctahedral-trioctahedral mica belonging to the yanzhumingite-fluorophlogopite series.

\section{Geological background and studied samples}

The Buca della Vena (latitude $43^{\circ} 59^{\prime} \mathrm{N}$, longitude $10^{\circ} 18^{\prime}$ E) and Monte Arsiccio (latitude $43^{\circ} 58^{\prime} \mathrm{N}$, longitude $10^{\circ} 17^{\prime}$ E) mines exploited small ore bodies belonging to a series of pyrite \pm baryte \pm iron oxide ore deposits located in the southern Apuan Alps (D’Orazio et al. 2017, and references therein). In both localities, the ore bodies are hosted in the upper part of a metavolcanic-metasedimentary sequence of Paleozoic age, close to the contact with the overlying Triassic metadolostone (Grezzoni Formation). These rocks, as well as the ore bodies, have been affected by greenschist facies metamorphism during the Alpine orogeny. In addition, the basement rocks are affected by the Variscan orogeny. The geological setting of the Buca della Vena and Monte Arsiccio mines has been discussed by previous authors (e.g., Benvenuti et al. 1986; Costagliola et al. 1990). Since the end of the 1970s, Buca della Vena mine has been known for the occurrence of several rare mineral species (e.g., Orlandi and Dini 2004); among them there are thirteen new minerals, mainly represented by sulfosalts (e.g., Orlandi et al. 1999, 2007). The mineralogical discovery of the Monte Arsiccio mine is more recent and dates to the end of the 2000s. Since then, more than one hundred different minerals have been identified and, among them, ten new mineral species, mainly represented by sulfosalts (e.g., Orlandi et al. 2012; Biagioni et al. 2014) and sulfates (Biagioni et al. 2019, 2020).

Specimen of mica from both localities have been studied. The specimen from the Monte Arsiccio mine (hereafter indicated as MA) was collected at the Sant'Olga level and it is represented by brownish flakes hosted within metadolostone (Fig. 1a). The specimen from the Buca della Vena mine (hereafter indicated as BdV) is represented by dark green flakes of mica, associated with magnetite, and embedded in metadolostone (Fig. 1b). This specimen was sampled close to the contact between the ore bodies and the metadolostone lenses hosted within the ores; close to this contact, dolomite veins hosting greenish crystals of beryl have been collected. 


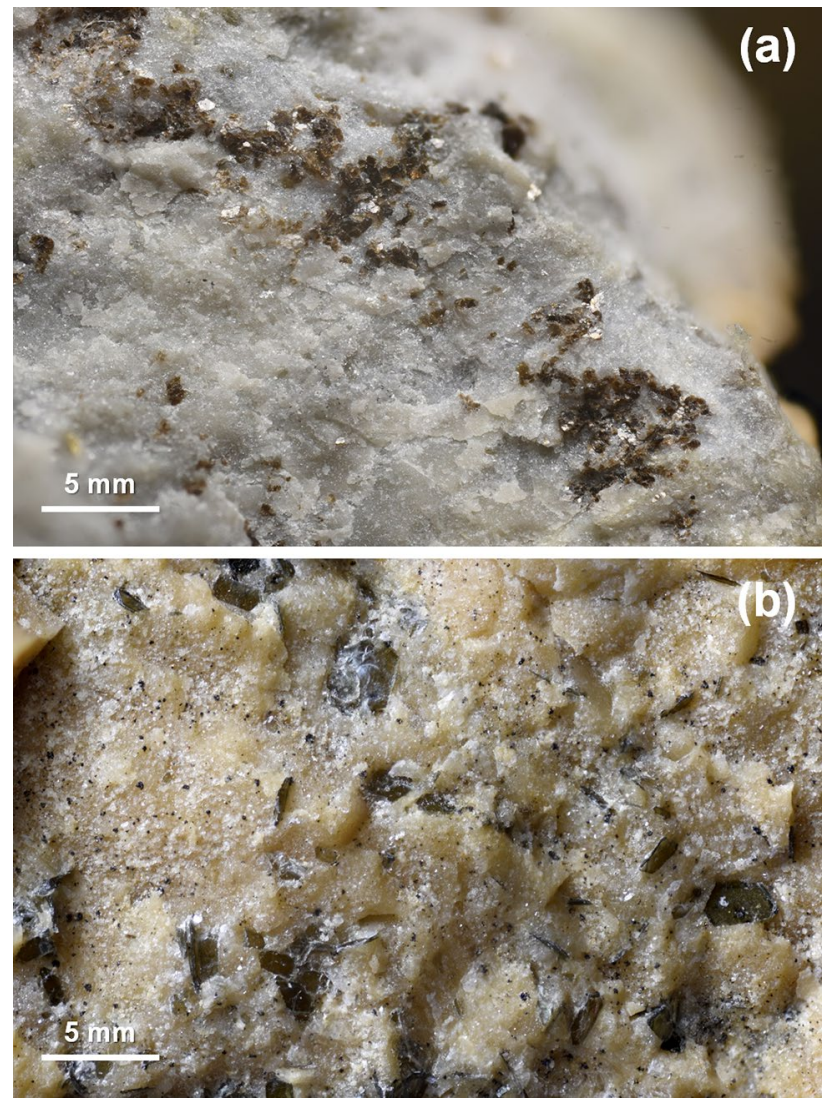

Fig. 1 a Brownish flakes of an intermediate member of the series yangzhumingite-fluorophlogopite in metadolostone. Sant'Olga level, Monte Arsiccio mine. b Greenish flakes of $(\mathrm{OH})$-rich fluorophlogopite from the Buca della Vena mine

\section{Analytical methods}

Several crystals from the specimen of the Monte Arsiccio and Buca della Vena mines were selected under an optical microscope and then checked for the crystal quality using SCXRD. Four of them, having a relatively good diffraction quality, were suitable for the intensity data collection and structure refinement; the same crystals were then used for chemical analyses and Raman spectroscopy.

EMP analyses were performed on crystals fixed with graphite glue to a graphite mount. A Superprobe JEOL JXA 8200 microprobe (WDS mode), installed at the Eugen F. Stumpfl laboratory (Leoben University, Austria) was used. The instrument operated at $10 \mathrm{kV}$ accelerating voltage, 10 $\mathrm{nA}$ beam current, $3 \mu \mathrm{m}$ beam diameter. Counting times were $15 \mathrm{~s}$ for peak and $5 \mathrm{~s}$ for background. The employed standards were: wollastonite ( $\mathrm{Si}$ and $\mathrm{Ca}$ ), sanidine ( $\mathrm{Na}, \mathrm{K}$ and $\mathrm{Al}$ ), olivine $(\mathrm{Fe}$ and $\mathrm{Mg}$ ), ilmenite (Ti), chromite $(\mathrm{Cr})$, vanadium $(\mathrm{V})$, rhodonite $(\mathrm{Mn})$, sphalerite $(\mathrm{Zn})$, skutterudite $(\mathrm{Ni})$, baryte $(\mathrm{Ba})$, fluorite $(\mathrm{F})$ and tugtupite $(\mathrm{Cl})$. The following diffracting crystals were selected: TAP for $\mathrm{Na}, \mathrm{Al}, \mathrm{Mg}$; LIFH
Table 1 Average chemical composition (wt $\%$ ) and atoms per formula unit (a.p.f.u.) calculated on the basis of $12(\mathrm{O}, \mathrm{OH}, \mathrm{F}, \mathrm{Cl})$ for the studied samples

\begin{tabular}{|c|c|c|c|c|}
\hline & MA_2 & MA_3 & $\mathrm{BdV}_{-} 1$ & BdV_5 \\
\hline $\mathrm{SiO}_{2}$ & 43.6(4) & $42.8(7)$ & $41.0(5)$ & $40.5(4)$ \\
\hline $\mathrm{Al}_{2} \mathrm{O}_{3}$ & 11.1(3) & $11.8(7)$ & $13.3(2)$ & $14.0(2)$ \\
\hline $\mathrm{MgO}$ & $18.8(4)$ & 19(1) & $19.3(4)$ & $19.4(3)$ \\
\hline $\mathrm{FeO}_{\mathrm{t}}^{\mathrm{a}}$ & $6.1(4)$ & $5.0(1)$ & $10.5(3)$ & $10.8(4)$ \\
\hline $\mathrm{TiO}_{2}$ & $0.53(5)$ & $0.89(6)$ & $0.07(5)$ & $0.09(4)$ \\
\hline $\mathrm{Cr}_{2} \mathrm{O}_{3}$ & $0.14(4)$ & $0.11(1)$ & $0.06(2)$ & $0.05(4)$ \\
\hline $\mathrm{V}_{2} \mathrm{O}_{3}$ & b.d.l. & b.d.l. & $0.03(2)$ & $0.06(4)$ \\
\hline $\mathrm{MnO}$ & b.d.l. & b.d.1. & $0.03(2)$ & $0.01(1)$ \\
\hline $\mathrm{ZnO}$ & $0.08(7)$ & n.d. & n.d. & n.d. \\
\hline $\mathrm{NiO}$ & $0.01(1)$ & b.d.1. & $0.05(3)$ & $0.05(4)$ \\
\hline $\mathrm{K}_{2} \mathrm{O}$ & $8.9(2)$ & $9.1(5)$ & $9.1(6)$ & $8.8(8)$ \\
\hline $\mathrm{Na}_{2} \mathrm{O}$ & $0.051(4)$ & $0.04(1)$ & $0.13(3)$ & $0.13(6)$ \\
\hline $\mathrm{BaO}$ & $3.1(1)$ & $3.1(1)$ & $0.11(4)$ & $0.11(3)$ \\
\hline $\mathrm{CaO}$ & $0.01(1)$ & $0.05(7)$ & $0.13(3)$ & b.d.l. \\
\hline $\mathrm{F}$ & $7.9(1)$ & $8.4(7)$ & $4.4(1)$ & $4.4(2)$ \\
\hline $\mathrm{Cl}$ & $0.1(1)$ & $0.2(2)$ & $0.7(3)$ & $0.8(3)$ \\
\hline Total & $100(1)$ & 101(2) & $98.9(3)$ & $99.2(6)$ \\
\hline$-\mathrm{O}=\mathrm{F}, \mathrm{Cl}$ & 3.33 & 3.58 & 2.00 & 2.03 \\
\hline $\mathrm{Si}$ & 3.26 & 3.18 & 3.13 & 3.09 \\
\hline $\mathrm{Al}$ & 0.97 & 1.03 & 1.20 & 1.26 \\
\hline $\mathrm{Mg}$ & 2.10 & 2.14 & 2.20 & 2.21 \\
\hline $\mathrm{Fe}$ & 0.38 & 0.31 & 0.67 & 0.69 \\
\hline $\mathrm{Ti}$ & 0.03 & 0.05 & - & - \\
\hline $\mathrm{Cr}$ & 0.01 & 0.01 & - & - \\
\hline $\mathrm{K}$ & 0.85 & 0.86 & 0.89 & 0.85 \\
\hline $\mathrm{Na}$ & 0.01 & 0.01 & 0.02 & 0.02 \\
\hline $\mathrm{Ba}$ & 0.09 & 0.09 & - & - \\
\hline $\mathrm{Ca}$ & - & - & 0.01 & - \\
\hline $\mathrm{F}$ & 1.86 & 1.97 & 1.06 & 1.07 \\
\hline $\mathrm{Cl}$ & 0.01 & 0.03 & 0.10 & 0.10 \\
\hline
\end{tabular}

${ }^{\mathrm{a}} \mathrm{FeO}_{\mathrm{t}}$ is total iron; b.d.1.= below detection limit; n.d. $=$ not determined. Standard deviations in parenthesis

for $\mathrm{Fe}, \mathrm{Ti}, \mathrm{Cr}, \mathrm{V}, \mathrm{Mn}, \mathrm{Zn}, \mathrm{Ni}$; PETJ for $\mathrm{Si}, \mathrm{Ca}, \mathrm{K}, \mathrm{Ba}, \mathrm{Cl}$; and $\mathrm{LDE} 1$ for $\mathrm{F}$. The $K \alpha \mathrm{X}$-ray line was used for all the analyzed elements except for the $L \alpha$ of Ba. Detection limits $(\mu \mathrm{g} / \mathrm{g})$ are: $\mathrm{Si}$ (300), Al (100), Mg (150), Fe (250), Ti (150), Cr (300), V (800), Mn (150), Zn (200), Ni (200), K (100), Na (150), Ba (200), $\mathrm{Ca}(100), \mathrm{F}(300)$ and $\mathrm{Cl}$ (900). The obtained oxides (wt\%) are the average of 3 to 8 spot analyses (see Table 1). Atomic proportions per formula unit (a.p.f.u.) based on $12(\mathrm{O}, \mathrm{OH}, \mathrm{F}, \mathrm{Cl})$ are also listed in the table. The $\mathrm{Li}_{2} \mathrm{O}$ content was not measured for the studied samples. However, since lithium was previously found in yangzhumingite, the $\mathrm{Li}_{2} \mathrm{O}$ content was estimated for the studied MA samples basing on the Eq. 1 in Tischendorf (1999), see details in the Discussion section. The equation was also tested on samples whose lithium content was measured by ICP-MS or SIMS 
(i.e. yangzhumingite in Schingaro et al. 2014; Ti-phlogopite in Scordari et al. 2008) and the calculated results were found very close to the experimental ones.

SCXRD data were collected by means of a Bruker AXS X8 APEXII automated diffractometer equipped with a CCD detector and graphite-monochromatized Mo $K \alpha$ radiation ( $\lambda=0.71073 \AA$ ) operating at $50 \mathrm{kV}, 30 \mathrm{~mA}$ and $40 \mathrm{~mm}$ crystal-to-detector distance. The whole Ewald sphere $( \pm h, \pm k, \pm l)$ was recorded up to $\theta \sim 35^{\circ}$ with a scan width $1.0^{\circ} /$ frame and an exposure time $10 \mathrm{~s} /$ frame. The APEX program suite allowed to optimize the collection strategy (Bruker 2010) whereas the SAINT package (Bruker 2007) was used for the integration of the intensities of reflections and the correction of the Lorentz and polarization effects. The SADABS software (Bruker 2009) was employed for the empirical absorption correction; XPREP (Sheldrick 2008) was used for the subsequent analysis of the intensity data and the assignment of the space group. Structure refinements were carried out by means of the program CRYSTALS (Betteridge et al. 2003) using the reflections with $I>3 \sigma(I)$. Overall scale factor, atomic positions, cation occupancies and anisotropic atomic displacement parameters were refined, starting from the coordinates of fluorophlogopite given by Lacalamita et al. (2017). The occupancy of the tetrahedral site was constrained to 1 . In the octahedral site, the $\mathrm{Mg}$ vs Fe occupancies were varied with full occupancy constraint for the BdV samples whereas for the MA crystals a restraint
$(0.8 \pm 0.1)$, in keeping with the chemical analyses, on the occupancy of the $\mathrm{Mg}+\mathrm{Fe}$ atoms was initially applied and then removed in the final cycles of the refinement. At the interlayer site, the $\mathrm{K}$ vs Ba occupancies were varied with a full occupancy constraint for the MA crystals; a restraint $(1.00 \pm 0.08)$ on the occupancy of the $\mathrm{K}$ atoms was, instead, used for the BdV crystals to allow the occupancy of this site to assume values higher or lower than 1 . The analysis of the difference-Fourier map of the BdV samples showed the presence of a residual electron density peak $\sim 1.1 e^{-} / \AA^{3}$ which may be interpreted as the position of the hydrogen atom (being at $\sim 0.67 \AA$ from the $\mathrm{O} 4$ oxygen). The hydrogen atoms were refined with soft restraints on the bond lengths to regularize their geometry $(\mathrm{O}-\mathrm{H}=0.90 \AA)$ as well as on $U_{\text {iso }}(\mathrm{H})$ (that could vary in the range $1.2-1.5$ times $U_{\text {eq }}$ of the parent atom); the hydrogen atomic coordinates were also refined with riding constraints (Cooper et al. 2010).

Relevant crystallographic data of the analysed samples and experimental data are reported in Table 2. Fractional atomic coordinates, site occupancies, and atomic displacement parameters are listed in Table S1, whereas selected cation-anion bond lengths and distortion parameters are included in Tables 3 and S2, respectively.

Raman spectra were collected on unpolished crystals. For the BdV sample, a LabRAM HR Evolution spectrometer (installed at the University of Bari), equipped with a binocular Olympus microscope, an ultra-low frequency
Table 2 Crystallographic data, acquisition parameters and details of the structure refinements for the studied samples

\begin{tabular}{lllll}
\hline & MA_2 & MA_3 & BdV ${ }^{1}$ & BdV_5 \\
\hline Crystal size $(\mathrm{mm})^{3}$ & $0.21 \times 0.20 \times 0.03$ & $0.30 \times 0.15 \times 0.04$ & $0.31 \times 0.27 \times 0.05$ & $0.55 \times 0.30 \times 0.06$ \\
Space group & $C 2 / m$ & $C 2 / m$ & $C 2 / m$ & $C 2 / m$ \\
$a(\AA)$ & $5.3025(3)$ & $5.3020(4)$ & $5.3244(2)$ & $5.3274(3)$ \\
$b(\AA)$ & $9.1846(5)$ & $9.1802(7)$ & $9.2206(2)$ & $9.2192(5)$ \\
$c(\AA)$ & $10.1472(6)$ & $10.1412(9)$ & $10.2286(3)$ & $10.2243(5)$ \\
$\beta\left({ }^{\circ}\right)$ & $100.165(5)$ & $100.066(7)$ & $100.087(2)$ & $100.101(4)$ \\
Cell volume $\left(\AA^{3}\right)$ & $486.43(5)$ & $486.01(7)$ & $494.40(3)$ & $494.38(5)$ \\
$Z$ & 4 & 4 & 4 & 4 \\
Reflections collected & 5620 & 5656 & 7474 & 7251 \\
Reflections unique & 788 & 787 & 1252 & 1256 \\
$R_{\text {merging }}\left[R_{\text {(int }}\right](\%)$ & 7.09 & 5.68 & 3.32 & 3.64 \\
Reflections used $(I>3 \sigma(I))$ & 506 & 587 & 914 & 885 \\
No. of refined parameters & 58 & 58 & 57 & 57 \\
Goof ${ }^{\mathrm{a}}$ & 1.031 & 1.024 & 1.087 & 1.053 \\
$R_{1}^{\mathrm{b}}(\%)$ & 3.54 & 4.46 & 3.27 & 4.37 \\
$w R_{2}^{\mathrm{c}}(\%)$ & 3.84 & 4.59 & 3.93 & 5.66 \\
$\Delta \rho_{\text {min }} / \Delta \rho_{\text {max }}\left(e^{-} / \AA^{3}\right)$ & $-0.44 / 0.73$ & $-0.88 / 1.02$ & $-0.47 / 1.01$ & $-0.67 / 1.59$ \\
\hline
\end{tabular}

${ }^{\mathrm{a}}$ Goodness-of-fit $=\left[\Sigma\left[w\left(F_{\mathrm{o}}{ }^{2}-F_{\mathrm{c}}\right)^{2}\right] /(N-p)\right]^{1 / 2}$, where $N$ and $p$ are the number of reflections and parameters, respectively

${ }^{\mathrm{b}} R_{1}=\Sigma\left[\left|F_{\mathrm{o}}\right|-\left|F_{\mathrm{c}}\right|\right] / \Sigma\left|F_{\mathrm{o}}\right|$

${ }^{\mathrm{c}} w R_{2}=\left[\Sigma\left[w\left(F_{\mathrm{o}}-F_{\mathrm{c}}\right)^{2}\right] / \Sigma\left[w\left(F_{\mathrm{o}}\right)^{2}\right]\right]^{1 / 2} ; w=$ Chebyshev optimized weights for the BdV samples and quasi unit for the MA samples 
Table 3 Selected bond distances $(\AA)$, mean distances $(\AA)$ and mean atomic numbers (electrons, $e^{-}$) of cation sites derived by structure refinements (X-ref) and chemical analyses (EMP) of the studied micas

\begin{tabular}{|c|c|c|c|c|}
\hline & MA_2 & MA_3 & BdV_1 & BdV_5 \\
\hline$T-\mathrm{O} 1$ & $1.648(3)$ & $1.648(2)$ & $1.655(2)$ & $1.655(2)$ \\
\hline$T-\mathrm{O} 1^{\prime}$ & $1.650(3)$ & $1.651(2)$ & $1.655(2)$ & $1.656(2)$ \\
\hline$T-\mathrm{O} 2$ & $1.650(2)$ & $1.649(1)$ & $1.654(1)$ & $1.654(1)$ \\
\hline$T-\mathrm{O} 3$ & $1.642(2)$ & $1.639(2)$ & $1.650(2)$ & $1.652(2)$ \\
\hline$<T-\mathrm{O}>$ & $1.647(5)$ & $1.647(4)$ & $1.654(4)$ & $1.654(4)$ \\
\hline$M 1-\mathrm{O} 4(\times 2)$ & $2.044(4)$ & $2.044(2)$ & $2.054(2)$ & $2.055(3)$ \\
\hline$M 1-\mathrm{O} 3(\times 4)$ & $2.092(3)$ & $2.088(1)$ & $2.091(2)$ & $2.092(2)$ \\
\hline$<M 1-\mathrm{O}>$ & $2.076(4)$ & $2.073(2)$ & $2.079(3)$ & $2.080(4)$ \\
\hline$M 2-\mathrm{O} 4(\times 2)$ & $2.034(2)$ & $2.032(2)$ & $2.055(2)$ & $2.059(2)$ \\
\hline$M 2-\mathrm{O} 3(\times 2)$ & $2.072(3)$ & $2.075(2)$ & $2.076(2)$ & $2.074(2)$ \\
\hline$M 2-\mathrm{O}^{\prime}(\times 2)$ & $2.075(3)$ & $2.075(2)$ & $2.083(2)$ & $2.081(2)$ \\
\hline$<M 2-\mathrm{O}>$ & $2.060(3)$ & $2.061(2)$ & $2.071(3)$ & $2.071(3)$ \\
\hline$<M-\mathrm{O}>$ & $2.065(5)$ & $2.065(3)$ & $2.074(4)$ & $2.074(5)$ \\
\hline$K-\mathrm{O} 1(\times 4)$ & $3.013(4)$ & $3.018(2)$ & $3.015(2)$ & $3.013(2)$ \\
\hline$K-\mathrm{O} 1^{\prime}(\times 4)$ & $3.239(3)$ & $3.229(2)$ & $3.302(2)$ & $3.305(3)$ \\
\hline$K-\mathrm{O} 2(\times 2)$ & $3.010(5)$ & $3.022(2)$ & $3.011(3)$ & $3.014(3)$ \\
\hline$K-\mathrm{O} 2^{\prime}(\times 2)$ & $3.245(5)$ & $3.229(3)$ & $3.312(3)$ & $3.307(4)$ \\
\hline$<K-\mathrm{O}\rangle_{\text {inner }}$ & $3.012(5)$ & $3.019(3)$ & $3.014(4)$ & $3.013(4)$ \\
\hline$<K-\mathrm{O}\rangle_{\text {outer }}$ & $3.241(5)$ & $3.229(3)$ & $3.305(4)$ & $3.306(5)$ \\
\hline$<T-\mathrm{O}\rangle_{\mathrm{X} \text {-ref }}$ & $1.647(7)$ & $1.647(4)$ & $1.654(4)$ & $1.654(4)$ \\
\hline$<T-\mathrm{O}\rangle_{\text {EMP }}$ & 1.645 & 1.647 & 1.652 & 1.654 \\
\hline$\langle M-\mathrm{O}\rangle_{\mathrm{X} \text {-ref }}$ & $2.065(5)$ & $2.065(3)$ & $2.074(4)$ & $2.074(5)$ \\
\hline$<M-\mathrm{O}\rangle_{\mathrm{EMP}}$ & 2.067 & 2.056 & 2.060 & 2.059 \\
\hline$T e^{-}$X-ref & 14.00 & 14.00 & 14.00 & 14.00 \\
\hline$T e^{-}$EMP & 13.81 & 13.79 & 13.75 & 13.74 \\
\hline$e^{-}(M 1) \mathrm{X}$-ref & 12.58 & 12.21 & 14.23 & 14.27 \\
\hline$e^{-}{ }_{(M 2)}$ X-ref & 12.70 & 12.49 & 14.44 & 14.56 \\
\hline$e^{-}(M 1+2 M 2) \mathrm{X}$-ref & 37.98 & 37.20 & 43.10 & 43.39 \\
\hline$e^{-}(M 1+2 M 2) \mathrm{EMP}$ & 38.37 & 37.07 & 44.43 & 44.55 \\
\hline$K e^{-}$X-ref & 22.79 & 22.64 & 16.17 & 14.99 \\
\hline$K e^{-}$ЕМР & 21.11 & 21.49 & 16.57 & 15.80 \\
\hline
\end{tabular}

Average error for mean atomic numbers is $\pm 0.5 e^{-}$

(ULF) filter, 600 and $1800 \mathrm{gr} / \mathrm{mm}$ gratings, a $632 \mathrm{~nm}$ $\mathrm{He}-\mathrm{Ne}$ laser and a Peltier-cooled CCD detector was used. The system was calibrated using the $520.5 \mathrm{~cm}^{-1}$ line of a silicon wafer before each experimental session. The spectrum was collected using a $100 \times$ objective, an exposure time of $120 \mathrm{~s}$ and averaging three repeated acquisitions. Raman spectrum of the Monte Arsiccio sample was collected using a Horiba Jobin-Yvon XploRA Plus apparatus (installed at the Dipartimento di Scienze della Terra, University of Pisa), equipped with a motorized $x-y$ stage and an Olympus BX41 microscope with a $10 \times$ objective. Raman spectra were excited using a $532 \mathrm{~nm}$ line of a solidstate laser, attenuated to $50 \%$ (i.e., $12.5 \mathrm{~mW}$ ). No sample damage was observed. The minimum lateral and depth resolution was set to a few $\mu \mathrm{m}$. The system was calibrated using the $520.5 \mathrm{~cm}^{-1}$ Raman band of silicon before each experimental session. Spectra were collected through multiple acquisitions (3) with a counting time of $120 \mathrm{~s}$. Backscattered radiation was analysed with a $1200 \mathrm{gr} / \mathrm{mm}$ grating monochromator.

The spectra of the Monte Arsiccio and Buca della Vena samples are shown in Fig. 3a, b, respectively.

\section{Results}

\section{Chemical composition}

Samples of mica from Monte Arsiccio show a Si content ( 3.22 a.p.f.u. on average, Table 1) intermediate between that of fluorophlogopite (2.91 Si a.p.f.u., Joswig 1972) and yangzhumingite (3.96 Si a.p.f.u., Miyawaki et al. 2011; 3.66 Si a.p.f.u., Schingaro et al. 2014; $3.76 \mathrm{Si}$ a.p.f.u., Shchipalkina et al. 2020) or, in general, natural tetrasilicic mica (3.67 Si a.p.f.u. for montdorite in Robert and Maury 1979; 3.34-3.8 Si a.p.f.u. for samples in Izraeli et al. 2004 and Klein-BenDavid et al. 2006; 3.98 Si a.p.f.u. for shirokshinite in Pekov et al. 2003). On the contrary, the $(\mathrm{Mg}+\mathrm{Fe})$ content of the MA samples (2.47 a.p.f.u. on average, Table 1) is similar to that of yangzhumingite and lower than that found in fluorophlogopite ( 2.9 a.p.f.u. in Gianfagna et al. 2007; Lacalamita et al. 2017). High contents of fluorine (1.92 a.p.f.u., Table 1) characterize the MA crystals as well as yangzhumingite and fluorophlogopite (e.g. Lacalamita et al. 2017 and references therein).

The chemical composition of the BdV samples differs from that of the Monte Arsiccio crystals. In particular, the $F$ amount of the BdV micas is one half that of the MA crystals (on average 1.1 vs 1.9 a.p.f.u., respectively, Table 1) whereas the Fe content of the BdV sample is almost twice than that of the Monte Arsiccio mica (on average 0.7 vs 0.3 a.p.f.u., respectively, Table 1).

\section{Structural details}

Structure refinements converged to good values of the agreement factors $R_{1}(3.27-4.46 \%)$ and $w R_{2}(3.84-5.66 \%)$, see Table 2 . All the analysed samples belong to the $1 M$ polytype and have $C 2 / m$ symmetry. 


\section{Yangzhumingite-fluorophlogopite series}

The two studied MA crystals exhibit almost the same unitcell parameters which are, on average, $a \sim 5.30, b \sim 9.18$, $c \sim 10.14 \AA, \beta \sim 100.12^{\circ}, V \sim 486.22 \AA^{3}$ (see Table 2). The value of the $c$ cell parameter in mica strictly depends on the anionic content (Cruciani and Zanazzi 1994; Ventruti et al. 2008; Ottolini et al. 2010; Zema et al. 2010; Scordari et al. 2013). Figure 2 shows the correlation between the $c$ parameter and the $\mathrm{F}^{-}+\mathrm{O}^{2-}$ content for micas with composition close to yangzhumingite and fluorophlogopite. An inverse trend is defined by the MA samples and most of the literature yangzhumingite and fluorophlogopite on one side, and the $(\mathrm{OH})$-analogue of yangzhumingite (Seifert and Schreyer 1971) and hypersilic Cl-mica (Nazzareni et al. 2008) on the other. The Russian yangzhumingite (Shchipalkina et al. 2020) and the fluorophlogopite in Hazen et al. (1981) fall out of the trend because the $c$ cell parameter $(\sim 10.20 \AA)$ is affected by the occurrence of $\mathrm{Fe}^{3+}$ in the tetrahedral site. On

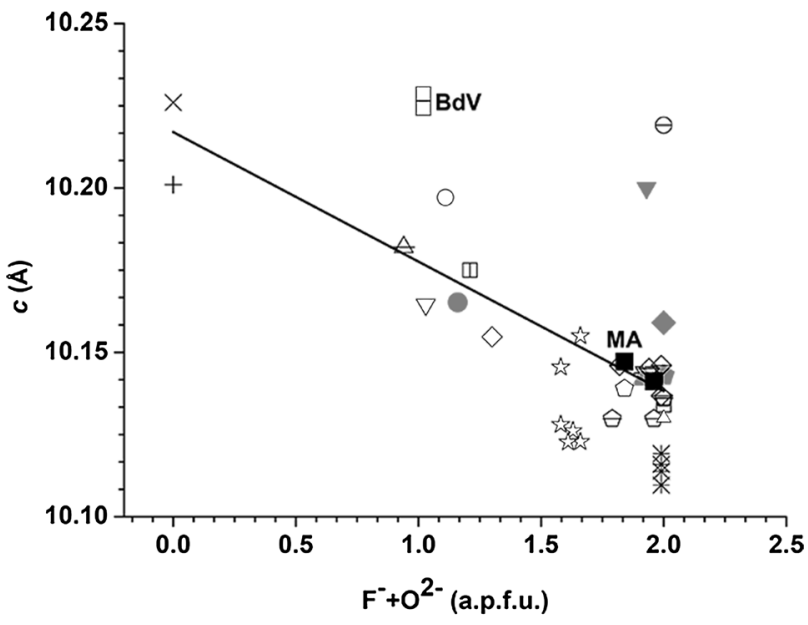

Fig. 2 c cell parameter $(\AA)$ plotted versus the $\mathrm{F}^{-}+\mathrm{O}^{2-}$ content (a.p.f.u.). Solid symbols for micas with composition close to yangzhumingite [black square: MA crystals in this study; gray circle: Schingaro et al. (2014); gray triangle pointing upward: Miyawaki et al. (2011); gray triangle pointing downward: Shchipalkina et al. (2020); gray diamond: Toraya et al. (1976); gray pentagon: Toraya et al. (1978)]. Plus symbol: $(\mathrm{OH})$-analogue of yangzhumingite in Seifert and Schreyer (1971); cross symbol: hypersilic Cl-mica in Nazzareni et al. (2008); square with vertical line: montdorite in Robert and Maury (1979). Open symbols for literature fluorophlogopite [square: BdV crystals in this study; circle: Schingaro et al. (2014); triangle pointing upward: Takeda and Donnay (1966); triangle pointing downward: Joswig (1972); diamond: Hazen and Burnham (1973); pentagon: McCauley et al. (1973); square with horizontal line: Takeda and Morosin (1975); circle with horizontal line: Hazen et al. (1981); triangle pointing upward with horizontal line: Russell and Guggenheim (1999); triangle pointing downward with horizontal line: Gianfagna et al. (2007); diamond with horizontal line: Balassone et al. (2013); pentagon with horizontal line: Lacalamita et al. (2017); star: Schingaro et al. (2011); asterisk: Scordari et al. (2013)]. The line is a guide to the eye the contrary, fluorophlogopite samples studied by Scordari et al. (2013) and Schingaro et al. (2011) exhibit the shortest $c$ cell parameters $(\sim 10.12 \AA)$ due to the additional significant oxy-substitutions $\left(\mathrm{OH}^{-} \rightarrow \mathrm{O}^{2-}\right.$ replacement) associated to the Ti-incorporation in the octahedral site.

The values of the $a$ and $b$ parameters of the studied MA samples, instead, are related to the composition of the octahedral sites (Zema et al. 2010). X-ray site scattering refinement of the MA_1 crystal provided similar Fe and $\mathrm{Mg}$ occupancies for the $M 1$ and $M 2$ sites (Table S1). Analogous results were also obtained for the MA_3 crystal. In addition, for both samples the $\langle M 1-\mathrm{O}\rangle$ distance is longer than the $\langle M 2-\mathrm{O}>$ one $(\sim 2.074$ vs $2.061 \AA$, see Table 3$)$, likely due to a preference of vacancies for the $M 1$ site. Therefore, the crystals are geometrically "meso-octahedral" (Weiss et al. 1985, 1992). Regarding individual distances, the M1-O4 and M2-O4 ones are the shortest due to the F for $\mathrm{OH}$ substitution at the $\mathrm{O} 4$ site. Similar structural features were previously found for the Kvaløya yangzhumingite by Schingaro et al. (2011). The synthetic tetrasilicic fluormica in Toraya et al. $(1976,1978)$, having only $\mathrm{Mg}$ in the octahedral sites, showed short values $(\sim 2.063 \AA$ ) for both the $\langle M 1-\mathrm{O}\rangle$ and $\langle M 2-\mathrm{O}\rangle$ distances.

Finally, the mean tetrahedral bond length $(\sim 1.647 \AA)$ of the studied MA crystals is close to that of fluorophlogopite (see Lacalamita et al. 2017 and references therein) thus indicating similar $\mathrm{Si} / \mathrm{Al}$ ratio. The greater $\mathrm{Si}$ content causes the shortening of the mean tetrahedral distances in the Kvaløya yangzhumingite $(<T-\mathrm{O}>=1.635(2) \AA$, Schingaro et al. 2014) and, especially, in the $\mathrm{KMg}_{2.50} \mathrm{Si}_{4} \mathrm{O}_{10} \mathrm{~F}_{2}$ mica $(<T-\mathrm{O}\rangle=1.625 \AA$, Toraya et al. 1976).

\section{(OH)-rich fluorophlogopite}

The BdV crystals show the following unit-cell parameters: $a \sim 5.33, b \sim 9.22, c \sim 10.23 \AA, \beta=100.09^{\circ}, V=494.4 \AA^{3}$ (Table 2). The $c$ axis is intermediate between that of the MA crystals and fluorophlogopite (see above), and the endmember phlogopite ( $c=10.310(6) \AA$, Redhammer and Roth 2002). The samples fall out of the trend in Fig. 2, showing a $c$ parameter larger than those of other literature $(\mathrm{OH})$-rich fluorphlogopites (Joswig 1972; Russell and Guggenheim 1999; Schingaro et al. 2014) which accounts for differences in the tetrahedral and octahedral site composition.

The $a$ and $b$ axes of the $\mathrm{BdV}$ crystals are elongated with respect to those of the MA samples, in agreement with the higher iron content in the octahedral sites (e.g. $M 1=84 \% \mathrm{Mg}$ and $16 \% \mathrm{Fe}, M 2=82 \% \mathrm{Mg}$ and $18 \% \mathrm{Fe}$ in BdV_1 crystal). Coherently, the $<M-\mathrm{O}>$ distances are larger than those of MA ( 2.074 ̊ vs $2.065 \AA$, respectively). The BdV crystals differ from the MA ones also in the tetrahedral size, showing a larger $<T-\mathrm{O}>$ distance $(1.654 \AA$ vs $1.647 \AA$, respectively) which suggests a lower $\mathrm{Si} / \mathrm{Al}$ content in the former samples. 
The difference between the $\langle K-\mathrm{O}\rangle_{\text {inner }}$ and $\langle K-\mathrm{O}\rangle_{\text {outer }}$ distances leads to $\Delta_{K-\mathrm{O}}=0.29$ in the $\mathrm{BdV}$ and $\Delta_{K-\mathrm{O}} \sim 0.21$ (Table S2) in the MA crystals, highlighting slight differences in the composition of the interlayer site.

\section{Raman spectra}

Figure 3a illustrates the Raman spectrum $\left(3800-100 \mathrm{~cm}^{-1}\right.$ ) of the MA_2 sample. In the low frequency range $\left(1100-100 \mathrm{~cm}^{-1}\right)$, broad and weak bands at 1077 and $890 \mathrm{~cm}^{-1}$ due to $\mathrm{Si}-\mathrm{O}$ antisymmetric internal modes as well as a sharp band at $679 \mathrm{~cm}^{-1}$ due to symmetric $\mathrm{Si}-\mathrm{O}-\mathrm{Si}$ modes are observed. Below $600 \mathrm{~cm}^{-1}$, a series of bands (at 534, 319, 270 and $187 \mathrm{~cm}^{-1}$ ) occur; they can be assigned to $\mathrm{Si}-\mathrm{O}$ deformation modes, internal $\mathrm{MO}_{6}$ vibrations and $\mathrm{M}-(\mathrm{OH})$ librations. Similar spectral features were observed for the BdV sample (Fig. 3b).

In the O-H stretching region (4000-3000 $\mathrm{cm}^{-1}$ ), the Raman spectrum of the MA mica is noisy and only very weak signals may be identified at $~ 3690$ and $3580 \mathrm{~cm}^{-1}$. On the contrary, in the same region, a well-defined Raman signal was found for the BdV mica (Fig. 3b). In particular, a broad band at $3595 \mathrm{~cm}^{-1}$ (with shoulders at 3611 and $3565 \mathrm{~cm}^{-1}$ ), likely due to $\mathrm{OH}$ groups bonded to $2 \mathrm{Mg}$ and adjacent to an octahedral vacancy, is associated to a high intensity peak centered at $3702 \mathrm{~cm}^{-1}$ which may be assigned to $\mathrm{MgMgMg}$ $\mathrm{OH}$ and/or $\mathrm{MgMgFe}^{2+}-\mathrm{OH}$ local environments.

The Raman band assignment agrees with that reported in literature for phyllosilicates (e.g. Wang et al. 2015; Moro et al. 2017). In summary, the Raman analysis highlights differences in the $\mathrm{OH}$ content between the two studied mica specimen as well as the occurrence of octahedral vacancy substitutions. These evidences are in keeping with the crystal-chemical formulae in Table 4 and with the derived substitution mechanisms (see more details below).

\section{Discussion}

Table 4 lists the crystal-chemical formulae of the studied crystals which were calculated combining the EMP data with the results of the SCXRD and Raman spectroscopy following the procedure explained elsewhere (see, for instance, Schingaro et al. 2013; Lacalamita et al. 2017).

\section{Yangzhumingite-fluorophlogopite series}

The crystal-chemical formulae of the MA crystals are balanced by several substitution mechanisms: (1) kinoshitalite $\left({ }^{\mathrm{XI}} \mathrm{K}^{+}+{ }^{\mathrm{IV}} \mathrm{Si}^{4+} \leftrightarrow{ }^{\mathrm{XII}} \mathrm{Ba}^{2+}+{ }^{\mathrm{IV}} \mathrm{Al}^{3+}\right)$; (2) yangzhumingite $\left(2^{\mathrm{XII}} \mathrm{K}^{+}+{ }^{\mathrm{VI}} \square \leftrightarrow 2^{\mathrm{XII}} \square+{ }^{\mathrm{VI}} \mathrm{R}^{2+}\right.$, with $\left.\mathrm{R}^{2+}=\mathrm{Mg}, \mathrm{Fe}\right)$; (3) $\mathrm{R}^{3+}$-vacancy $\left(3^{\mathrm{VI}} \mathrm{R}^{2+} \leftrightarrow 2^{\mathrm{VI}} \mathrm{R}^{3+}+{ }^{\mathrm{VI}} \square\right.$, with $\mathrm{R}^{3+}=\mathrm{Al}$,
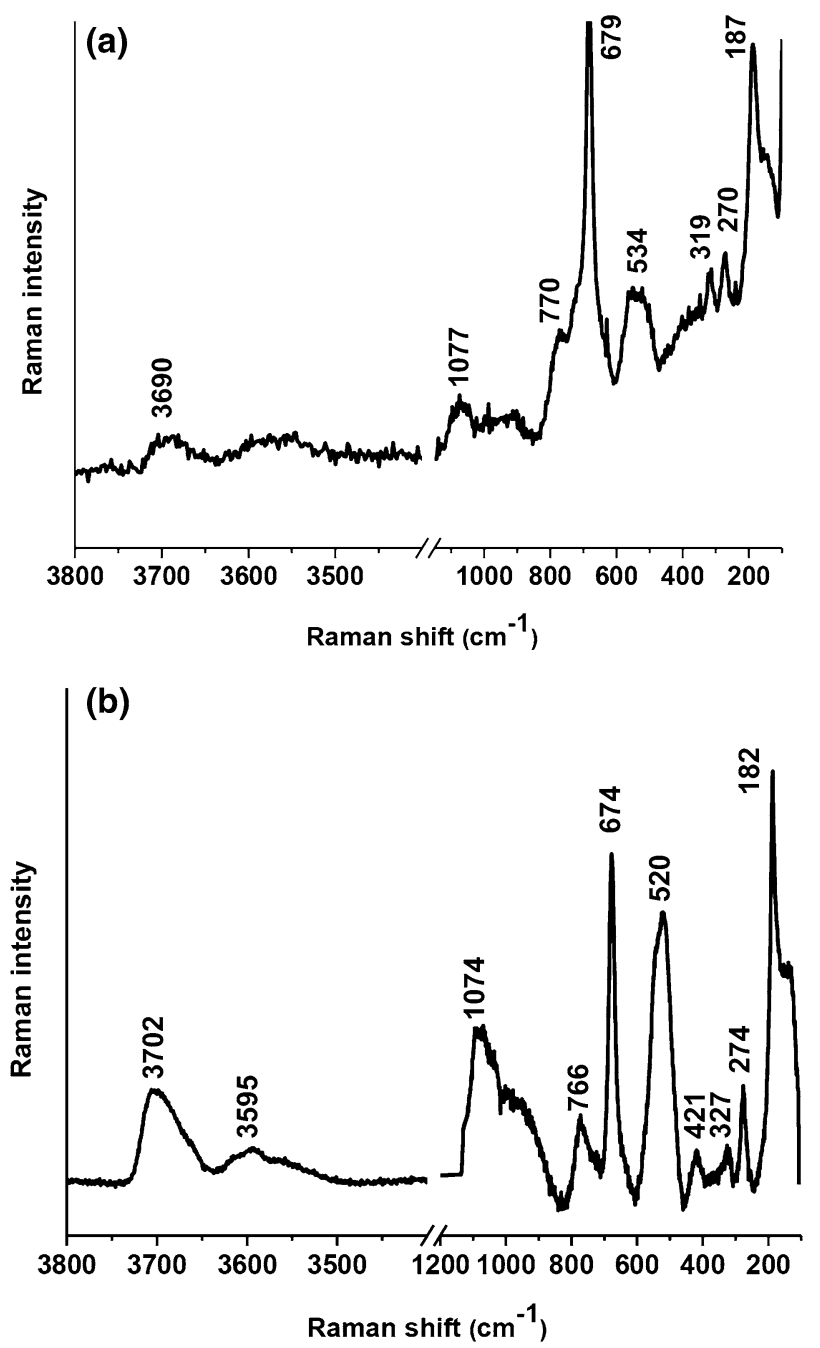

Fig. 3 Raman spectra of the Monte Arsiccio (a) and Buca della Vena (b) samples in the range $3800-100 \mathrm{~cm}^{-1}$

$\mathrm{Fe}^{3+}$ and $\mathrm{Cr}$ ) and Ti-vacancy $\left(2^{\mathrm{VI}} \mathrm{R}^{2+} \leftrightarrow{ }^{\mathrm{VI}} \mathrm{Ti}^{4+}+{ }^{\mathrm{VI}} \square\right)$; (4) $\mathrm{OH}^{-} \leftrightarrow \mathrm{F}^{-}$.

It can be noted that in the MA samples, the octahedral vacancies are justified by the mechanisms (2) and (3) (see crystal chemical formulae in Table 4) whereas in the Kvaløya yangzhumingite the dominant mechanism is (2).

This difference is reflected by the values of selected distortion parameters (see Table S2). In particular, the presence of high-charge cations in the octahedral sites of MA crystals entails greater distortion of the parameters D.M., ELD and OAV and lower $t_{\text {oct }}$ and volume ${ }_{M 2}$ in comparison to the Kv_Yan_sc sample in Schingaro et al. (2014). The low values of the shift $_{M 2}$ parameter is commonly related to the absence of oxy-type substitutions. Other distortion parameters (volume ${ }_{M 1}, \psi$ angles and BLD parameters in Table S2) seem less affected by the cation substitutions at the octahedral sites. 
Table 4 Crystal chemical formulae (in a.p.f.u.) of the studied samples compared with Kvaløya yangzhumingite

\begin{tabular}{|c|c|c|c|c|}
\hline & Sample & Interlayer site & Octahedral site & Tetrahedral site \\
\hline This study & MA_2 & $\left(\mathrm{K}_{0.84} \mathrm{Na}_{0.01} \mathrm{Ba}_{0.09}\right)_{\Sigma=0.94}$ & $\begin{array}{l}\left(\mathrm{Mg}_{2.08} \mathrm{Fe}^{2+}{ }_{0.31} \mathrm{Fe}^{3+}{ }_{0.07} \mathrm{Cr}^{3+}{ }_{0.01} \mathrm{Al}_{0.20}\right. \\
\left.\mathrm{Ti}_{0.03} \square_{0.30}\right)_{\Sigma=3.00}\end{array}$ & $\begin{aligned}\left(\mathrm{Si}_{3.23} \mathrm{Al}_{0.77}\right)_{\Sigma=4.00} & \mathrm{O}_{10.00} \mathrm{~F}_{1.84} \\
& \mathrm{Cl}_{0.01} \mathrm{OH}_{0.15}\end{aligned}$ \\
\hline This study & MA_3 & $\left(\mathrm{K}_{0.86} \mathrm{Na}_{0.01} \mathrm{Ba}_{0.09}\right)_{\Sigma=0.96}$ & $\begin{array}{l}\left(\mathrm{Mg}_{2.13} \mathrm{Fe}^{2+}{ }_{0.15} \mathrm{Fe}^{3+}{ }_{0.15} \mathrm{Cr}^{3+}{ }_{0.01} \mathrm{Al}_{0.18}\right. \\
\left.\mathrm{Ti}_{0.05} \square_{0.33}\right)_{\Sigma=3.00}\end{array}$ & $\left(\mathrm{Si}_{3.16} \mathrm{Al}_{0.84}\right)_{\Sigma=4.00} \mathrm{O}_{10.00} \mathrm{~F}_{1.96}$ \\
\hline Schingaro et al. (2014) & Kv_Yan_sc & $\left(\mathrm{K}_{0.98} \mathrm{Na}_{0.03}\right)_{\Sigma=1.01}$ & $\begin{array}{l}\left(\mathrm{Mg}_{2.35} \mathrm{Fe}^{2+}{ }_{0.23} \mathrm{Cr}_{0.01} \mathrm{Ti}_{0.02} \mathrm{Ni}_{0.01}\right. \\
\left.\square_{0.38}\right)_{\Sigma=3.00}\end{array}$ & $\left(\mathrm{Si}_{3.66} \mathrm{Al}_{0.34}\right)_{\Sigma=4.00} \mathrm{O}_{10.00} \mathrm{~F}_{1.16} \mathrm{OH}_{0.84}$ \\
\hline This study & BdV_1 & $\left(\mathrm{K}_{0.85} \mathrm{Na}_{0.02 \mathrm{Ca} 0.01}\right)_{\Sigma=0.88}$ & $\left(\mathrm{Mg}_{2.11} \mathrm{Fe}^{2+}{ }_{0.57} \mathrm{Fe}^{3+}{ }_{0.08} \mathrm{Al}_{0.17} \square_{0.07}\right)_{\Sigma=3.00}$ & $\begin{array}{r}\left(\mathrm{Si}_{3.01} \mathrm{Al}_{0.99}\right)_{\Sigma=4.00} \mathrm{O}_{10.00} \mathrm{~F}_{1.02} \\
\mathrm{Cl}_{0.09} \mathrm{OH}_{0.89}\end{array}$ \\
\hline This study & BdV_5 & $\left(\mathrm{K}_{0.82} \mathrm{Na}_{0.02}\right)_{\Sigma=0.84}$ & $\left(\mathrm{Mg}_{2.12} \mathrm{Fe}^{2+}{ }_{0.53} \mathrm{Fe}^{3+}{ }_{0.12} \mathrm{Al}_{0.17} \square_{0.05}\right)_{\Sigma=2.99}$ & $\begin{array}{r}\left(\mathrm{Si}_{2.96} \mathrm{Al}_{1.04}\right)_{\Sigma=4.00} \mathrm{O}_{10.00} \mathrm{~F}_{1.02} \\
\mathrm{Cl}_{0.09} \mathrm{OH}_{0.89}\end{array}$ \\
\hline
\end{tabular}

Table S2 also lists the tetrahedral distortion parameters. The Al-enrichment of the MA crystals with respect to Kvaløya yangzhumingite does not affect significantly the tetrahedral volume (2.24 vs $2.23 \AA^{3}$, Table S2) whereas it causes an increase of the in-plane rotation angle (on average $\alpha \sim 4.7$ vs $1.4^{\circ}$, Table S2) which represents the rotation of the individual tetrahedra to match the difference in sizes between the tetrahedral and octahedral sheets (Mercier et al. $2005)$. The higher the $\alpha$ rotation angle, the greater the difference between the $K-\mathrm{O}_{\text {outer }}$ and $K-\mathrm{O}_{\text {inner }}$ distances $\left(\Delta_{K-\mathrm{O}}\right.$ parameter in Table S2). In the case of the MA samples, this parameter is also affected by the relatively high amount of barium (0.10 Ba a.p.f.u.) in the interlayer site. In addition, the ${ }^{\mathrm{IV}} \mathrm{Al} \rightarrow{ }^{\mathrm{IV}} \mathrm{Si}$ substitution seems to regularize the tetrahedra as testified by the lower values of the $\mathrm{BLD}_{T}(0.2$ vs 0.6 , Table S2) and TAV (about 4.4 vs $8.9^{\circ}$, Table S2) parameters in the MA crystals with respect to the yangzhumingite. The MA samples also show a less corrugated tetrahedral sheet $(\Delta z \sim 0.003 \AA$ in the MA vs $0.008 \AA$ in the Kv_Yan_sc, see Table S2).

Finally, the estimated $\mathrm{Li}_{2} \mathrm{O}$ content $(0.02 \mathrm{wt} \%)$ in the studied samples corresponds to only $0.01 \mathrm{Li}$ a.p.f.u., which has a negligible effect on the crystal chemistry of the MA crystals. Low $\mathrm{Li}_{2} \mathrm{O}$ concentration $(0.006 \mathrm{wt} \%)$ was also detected in the Kvaløya yangzhumingite in comparison to the $0.30 \mathrm{Li}$ a.p.f.u. of the Bayan Obo yangzhumingite in Miyawaki et al. (2011).

\section{(OH)-rich fluorophlogopite}

The crystal-chemical formulae of the BdV crystals (Table 4) show that the main substitution mechanisms are: Al, $\mathrm{Fe}^{3+}$-Tschermak $\left[{ }^{\mathrm{VI}} \mathrm{M}^{2+}+{ }^{\mathrm{IV}} \mathrm{Si}^{4+} \leftrightarrow{ }^{\mathrm{VI}}\left(\mathrm{Al}^{3+}, \mathrm{Fe}^{3+}\right)+{ }^{\mathrm{IV}} \mathrm{Al}^{3+}\right]$; $\mathrm{R}^{3+}$-vacancy $\left(3^{\mathrm{VI}} \mathrm{R}^{2+} \leftrightarrow 2^{\mathrm{VI}} \mathrm{R}^{3+}+{ }^{\mathrm{VI}} \square\right.$, with $\left.\mathrm{R}^{3+}=\mathrm{Al}, \mathrm{Fe}^{3+}\right)$; $(\mathrm{OH})^{-} \leftrightarrow \mathrm{F}^{-}$. This mica differs from the MA for the higher ${ }^{\mathrm{IV}} \mathrm{Al}$ content (about 1 vs 0.8 a.p.f.u., Table 4 ) which explains the lower values of the $\mathrm{BLD}_{T}(\sim 0.1$ vs 0.2 , Table $\mathrm{S} 2)$ and TAV ( 2.4 vs $4.4^{\circ}$, Table S2) distortion parameters and the higher values of the $\alpha$ rotation angle $\left(\sim 6.4\right.$ vs $4.6^{\circ}$,
Table S2). As concern the octahedral site, the BdV crystals exhibit a higher ${ }^{\mathrm{VI}} \mathrm{R}^{2+}$ (i.e. $\mathrm{Mg}+\mathrm{Fe}^{2+}$ ) content ( 2.7 vs 2.4 a.p.f.u., Table 4$)$ and less vacancies ( $\sim 0.1$ vs 0.3 p.f.u.) with respect to the MA crystals. These features cause minor distortion of the $M 1$ and $M 2$ octahedra of the BdV crystals as testified by the values of the BLD, and OAV parameters in Table S2. Finally, the low extent of the $(\mathrm{OH})^{-} \leftrightarrow \mathrm{F}^{-}$substitution in the Buca della Vena mica with respect to the MA crystals is responsible for the larger interlayer separation $\left(t_{\text {int }} \sim 3.40\right.$ vs $3.31 \AA$, Table S2).

\section{Conclusions}

The present paper represents the first contribution to the knowledge of the crystal-chemistry of micas from the ore deposits of the Apuan Alps. The detailed comparative crystal-chemistry of the present study allowed to identify a mica with a peculiar composition. Indeed, the specimen from the Monte Arsiccio mine can be classified as an intermediate member in the yangzhumingite-fluorophlogopite series since it is characterized by the same substitution mechanisms active in the structure of the yangzhumingite, although its tetrahedral composition approximate that of a fluorophlogopite. This finding provides evidences of a solid solution between these two minerals.

The specimen of mica from Buca della Vena shows, instead, the typical crystal-chemical features of a $(\mathrm{OH})$-rich fluorophlogopite affected by vacancies substitutions.

In both cases, the occurrence of high $\mathrm{F}$ contents is particularly intriguing and could explain the finding of some fluo-sulfates recently described from the Apuan Alps ores and related to the interaction between $\mathrm{H}_{2} \mathrm{SO}_{4}$ released during pyrite weathering and (F-rich mica)-bearing country rocks (e.g., wilcoxite, khademite-Mauro et al. 2019, 2020). In addition, the sample from the Monte Arsiccio mine contains relatively high $\mathrm{Ba}$ contents. This is not an unexpected feature owing to the occurrence of several Ba-minerals (e.g., "hyalophane", cymrite, mannardite-Biagioni et al. 2009), 
in addition to widespread baryte. Consequently, considering also the variable geochemistry of the ore deposits from the southern Apuan Alps, extensive studies on mica group minerals should be carried out, in order to get new insights into the crystal-chemistry of $\mathrm{Ba}$ in micas, as well as to describe the chemical variability of these minerals in the Apuan Alps hydrothermal ores.

Acknowledgements The Raman spectrometer at the University of Bari (Dep. of Chemistry) was funded by Potenziamento Strutturale PONa3_00369 "Laboratorio per lo Sviluppo Integrato delle Scienze e delle Tecnologie dei Materiali Avanzati e per dispositivi innovativi (SISTEMA)". I. Pekov and an anonymous referee are gratefully acknowledged for their insightful suggestions.

Author contributions ML and CB conceived and coordinated the study. ML and EM contributed to SCXRD analysis; FZ contributed to EMP analysis; ML and CB contributed to Raman spectroscopic data. The first draft was written by ML and CB and all authors commented on the manuscript. ES revised the paper. All authors read and approved the final manuscript.

Funding Open access funding provided by Università degli Studi di Bari Aldo Moro within the CRUI-CARE Agreement. This research received support from Ministero dell'Istruzione, dell'Università e della Ricerca through the project SIR 2014 "THALMIGEN-Thallium: Mineralogy, Geochemistry, and Environmental Hazards", granted to CB (Grant no. RBSI14A1CV).

Availability of data and materials CIF files are provided. The remaining data are available.

\section{Compliance with ethical standards}

Conflict of interest The authors declare no conflicts of interest.

Code availability Not applicable.

Open Access This article is licensed under a Creative Commons Attribution 4.0 International License, which permits use, sharing, adaptation, distribution and reproduction in any medium or format, as long as you give appropriate credit to the original author(s) and the source, provide a link to the Creative Commons licence, and indicate if changes were made. The images or other third party material in this article are included in the article's Creative Commons licence, unless indicated otherwise in a credit line to the material. If material is not included in the article's Creative Commons licence and your intended use is not permitted by statutory regulation or exceeds the permitted use, you will need to obtain permission directly from the copyright holder. To view a copy of this licence, visit http://creativecommons.org/licenses/by/4.0/.

\section{References}

Balassone G, Scordari F, Lacalamita M, Schingaro E, Mormone A, Piochi M, Petti C, Mondillo N (2013) Trioctahedral micas in xenolithic ejecta from recent volcanism of the Somma-Vesuvius (Italy): crystal chemistry and genetic inferences. Lithos 160-161:84-97

Benvenuti M, Lattanzi P, Tanelli G, Cortecci G (1986) The Ba-Fepyrite deposit of Buca della Vena, Apuan Alps, Italy. Rend Soc Ital Mineral Petrol 41(2):347-358
Betteridge PW, Carruthers JR, Cooper RI, Prout K, Watkin DJ (2003) Crystals version 12: software for guided crystal structure analysis. J Appl Crystallogr 36:1487

Biagioni C, Bindi L, Mauro D, Hålenius U (2019) Crystal chemistry of sulfates from the Apuan Alps (Tuscany, Italy). V. Scordariite, $\mathrm{K}_{8}\left(\mathrm{Fe}^{3+}{ }_{0.67} \square_{0.33}\right)\left[\mathrm{Fe}^{3+}{ }_{3} \mathrm{O}\left(\mathrm{SO}_{4}\right)_{6}\left(\mathrm{H}_{2} \mathrm{O}\right)_{3}\right]_{2}\left(\mathrm{H}_{2} \mathrm{O}\right)_{11}$ : a new metavoltine-related mineral. Minerals 9(11):702

Biagioni C, Bindi L, Mauro D, Pasero M (2020) Crystal-chemistry of sulfates from the Apuan Alps (Tuscany, Italy). IV. Giacovazzoite, $\mathrm{K}_{5} \mathrm{Fe}^{3+}{ }_{3} \mathrm{O}\left(\mathrm{SO}_{4}\right)_{6}\left(\mathrm{H}_{2} \mathrm{O}\right)_{9} \cdot \mathrm{H}_{2} \mathrm{O}$, the natural analogue of the $\beta$-Maus's salt and its dehydration product. Phys Chem Miner 47(1):7

Biagioni C, Bonaccorsi E, Moëlo Y, Orlandi P, Bindi L, D’Orazio M, Vezzoni S (2014) Mercury-arsenic sulfosalts from the Apuan Alps (Tuscany, Italy). II. Arsiccioite, $\mathrm{AgHg}_{2} \mathrm{TlAs}_{2} \mathrm{~S}_{6}$, a new mineral from the Monte Arsiccio mine: occurrence, crystal structure and crystal chemistry of the routhierite isotypic series. Mineral Mag 78:101-117

Biagioni C, Orlandi P, Pasero M (2009) Ankangite from the Monte Arsiccio mine (Apuan Alps, Tuscany, Italy): occurrence, crystal structure, and classification problems in cryptomelane group minerals. Period Mineral 78:3-11

Bruker (2007) SAINT, Bruker AXS Inc., Madison, Wisconsin, USA

Bruker (2009) SADABS, Bruker AXS Inc., Madison, Wisconsin, USA

Bruker (2010) APEX2 v.2010.7-0, Bruker AXS Inc., Madison, Wisconsin, USA

Cooper RI, Thompson AL, Watkin DJ (2010) CRYSTALS enhancements: dealing with hydrogen atoms in refinement. J Appl Crystal$\operatorname{logr}$ 43:1100-1107

Costagliola P, Benvenuti M, Tanelli G, Cortecci G, Lattanzi P (1990) The barite-pyrite-iron oxides deposit of Monte Arsiccio (Apuane Alps). Geological setting, mineralogy, fluid inclusions, stable isotopes and genesis. B Soc Geol Ital 109:267-277

Cruciani G, Zanazzi PF (1994) Cation partitioning and substitution mechanisms in $1 M$ phlogopite: a crystal chemical study. Am Mineral 79:289-301

D’Orazio M, Biagioni C, Dini A, Vezzoni S (2017) Thallium-rich pyrite ores from the Apuan Alps, Tuscany, Italy: constraints for their origin and environmental concerns. Miner Deposita 52(5):687-707

Gianfagna A, Scordari F, Mazziotti-Tagliani S, Ventruti G, Ottolini L (2007) Fluorophlogopite from Biancavilla (Mt. Etna, Sicily, Italy): crystal structure and crystal chemistry of a new F-dominant analog of phlogopite. Am Mineral 92:1601-1609

Hazen RM, Burnham CW (1973) The crystal structures of one-layer phlogopite and annite. Am Mineral 58:889-900

Hazen RM, Finger LW, Velde D (1981) Crystal structure of a silicaand alkali-rich trioctahedral mica. Am Mineral 66:586-591

Izraeli ES, Harris JW, Navon O (2004) Fluid and mineral inclusions in cloudy diamonds from Koffiefontein, South Africa. Geochim Cosmochim Ac 68(11):2561-2575

Joswig VW (1972) Neutronenbeugungsmessungen an einem 1M-phlogopit. Neues Jb Miner Monat 1972:1-11

Klein-BenDavid O, Wirth R, Navon O (2006) TEM imaging and analysis of microinclusions in diamonds: a close look at diamondgrowing fluids. Am Mineral 91:353-365

Kullerud K, Zozulya D, Bergh SG, Hansen H, Ravna EJK (2011) Geochemistry and tectonic setting of a lamproite dyke in Kvaløya, North Norway. Lithos 126:278-289

Lacalamita M, Balassone G, Schingaro E, Mesto E, Mormone A, Piochi M, Ventruti G, Joachimski M (2017) Fluorophlogopitebearing and carbonate metamorphosed xenoliths from the Campanian Ignimbrite (Fiano, southern Italy): crystal chemical, geochemical and volcanological insights. Mineral Mag 81:1165-1189

Mauro D, Biagioni C, Pasero M, Skogby H (2019) Crystal-chemistry of sulfates from the Apuan Alps (Tuscany, Italy). III. Mg-rich 
sulfate assemblages from the Fornovolasco mining complex. Atti della Società Toscana di Scienze Naturali, Memorie 126:33-44

Mauro D, Biagioni C, Pasero M, Zaccarini F (2020) Crystal-chemistry of sulfates from the Apuan Alps (Tuscany, Italy). VIII. New data on khademite, $\mathrm{Al}\left(\mathrm{SO}_{4}\right) \mathrm{F}\left(\mathrm{H}_{2} \mathrm{O}\right)_{5}$. Mineral Mag 84:540-546

McCauley JW, Newnham RE, Gibbs GV (1973) Crystal structure analysis of synthetic fluorophlogopite. Am Mineral 58:249-254

Mercier PHJ, Evans RG, Rancourt DG (2005) Geometric crystal chemical models for structural analysis of micas and their stacking polytypes. Am Mineral 90:382-398

Miyawaki R, Shimazaki H, Shigeoka M, Yokoyama K, Matsubara S, Yurimoto $\mathrm{H}$ (2011) Yangzhumingite, $\mathrm{KMg}_{2.5} \mathrm{Si}_{4} \mathrm{O}_{10} \mathrm{~F}_{2}$, a new mineral in the mica group from Bayan Obo, Inner Mongolia, China. Eur J Mineral 23:467-473

Moro D, Valdrè G, Mesto E, Scordari F, Lacalamita M, Della Ventura G, Bellatreccia F, Scirè S, Schingaro E (2017) Hydrocarbons in phlogopite from Kasenyi kamafugitic rocks (SW Uganda): crosscorrelated AFM, confocal microscopy and Raman imaging. Sci Rep 7:40663

Nazzareni S, Comodi P, Bindi L, Safonov OG, Litvin YA, Perchuk LL (2008) Synthetic hypersilicic Cl-bearing mica in the phlogopiteceladonite join: a multimethodical characterization of the missing link between di- and tri-octahedral micas at high pressures. Am Mineral 93:1429-1436

Orlandi P, Biagioni C, Bonaccorsi E, Moëlo Y, Paar WH (2012) Leadantimony sulfosalts from Tuscany (Italy). XII. Boscardinite, $\mathrm{TlPb}_{4}\left(\mathrm{Sb}_{7} \mathrm{As}_{2}\right)_{\Sigma 9} \mathrm{~S}_{18}$, a new mineral species from the Monte Arsiccio mine: occurrence and crystal structure. Can Mineral 50:235-251

Orlandi P, Dini A (2004) Die mineralien der Buca della Vena-mine, Apuaner Berge, Toskana, Italien. Lapis 1:11-24

Orlandi P, Moëlo Y, Campostrini I, Meerschaut A (2007) Leadantimony sulfosalts from Tuscany (Italy). IX. Marrucciite, $\mathrm{Hg}_{3} \mathrm{~Pb}_{16} \mathrm{Sb}_{18} \mathrm{~S}_{46}$, a new sulfosalt from Buca della Vena mine, Apuan Alps: definition and crystal structure. Eur J Miner 19:267-279

Orlandi P, Moëlo Y, Meerschaut A, Palvadeau P (1999) Lead-antimony sulfosalts from Tuscany (Italy). I. Scainiite, $\mathrm{Pb}_{14} \mathrm{Sb}_{30} \mathrm{~S}_{54} \mathrm{O}_{5}$, the first $\mathrm{Pb}-\mathrm{Sb}$ oxy-sulfosalt, from Buca della Vena mine. Eur J Miner 11:949-954

Ottolini LP, Schingaro E, Scordari F, Mesto E, Lacalamita M (2010) The role of SIMS in the investigation of the complex crystal chemistry of mica minerals. IOP Conf Ser Mater Sci Eng 7:012023

Pekov IV, Chukanov NV, Ferraris G, Ivaldi G, Pushcharovsky DY, Zadov AE (2003) Shirokshinite, $\mathrm{K}\left(\mathrm{NaMg}_{2}\right) \mathrm{Si}_{4} \mathrm{O}_{10} \mathrm{~F}_{2}$, a new mica with octahedral Na from Khibiny massif, Kola Peninsula: descriptive data and structural disorder. Eur J Mineral 15:447-454

Redhammer GJ, Roth G (2002) Single-crystal structure refinements and crystal chemistry of synthetic trioctahedral micas $\mathrm{KM}_{3}\left(\mathrm{Al}^{3+}\right.$, $\left.\mathrm{Si}^{4+}\right)_{4} \mathrm{O}_{10}(\mathrm{OH})_{2}$, where $\mathrm{M}=\mathrm{Ni}^{2+}, \mathrm{Mg}^{2+}, \mathrm{Co}^{2+}, \mathrm{Fe}^{2+}$, or $\mathrm{Al}^{3+}$. Am Mineral 87:1464-1476

Robert J-L, Maury RC (1979) Natural occurrence of a (Fe, Mn, Mg) tetrasilicic potassium mica. Contrib Mineral Petr 68:117-123

Russell RL, Guggenheim S (1999) Crystal structures of near-endmember phlogopite at high temperatures and heat-treated $\mathrm{Fe}$ rich phlogopite; the influence of the $\mathrm{O}, \mathrm{OH}, \mathrm{F}$ site. Can Mineral 37:711-720

Schingaro E, Kullerud K, Lacalamita M, Mesto E, Scordari F, Zozulya D, Erambert M, Ravna EJK (2014) Yangzhumingite and phlogopite from the Kvaløya lamproite (North Norway): structure, composition and origin. Lithos 210:1-13
Schingaro E, Lacalamita M, Scordari F, Brigatti MF, Pedrazzi G (2011) Crystal chemistry of Ti-rich fluorophlogopite from Presidente Olegario, Alto Paranaíba igneous province, Brazil. Am Mineral 96:732-743

Schingaro E, Lacalamita M, Scordari F, Mesto E (2013) 3T-phlogopite from Kasenyi kamafugite (SW Uganda): EPMA, XPS, FTIR, and SCXRD study. Am Mineral 98:709-717

Scordari F, Schingaro E, Ventruti G, Lacalamita M, Ottolini L (2008) Red micas from basal ignimbrites of Mt. Vulture (Italy): interlayer content appraisal by a multi-methodic approach. Phys Chem Miner 35:163-174

Scordari F, Schingaro E, Ventruti G, Nicotra E, Viccaro M, Mazziotti Tagliani S (2013) Fluorophlogopite from Piano delle Concazze (Mt. Etna, Italy): crystal chemistry and implications for the crystallization conditions. Am Mineral 98:1017-1025

Seifert F, Schreyer W (1971) Synthesis and stability of micas in the system $\mathrm{K}_{2} \mathrm{O}-\mathrm{MgO}-\mathrm{SiO}_{2}-\mathrm{H}_{2} \mathrm{O}$ and their relations to phlogopite. Contrib Mineral Petrol 30:196-215

Shchipalkina NV, Pekov IV, Koshlyakova NN, Britvin SN, Zubkova NV, Varlamov DA, Sidorov EG (2020) Unusual silicate mineralization in fumarolic sublimates of the Tolbachik volcano, Kamchatka, Russia-part 1: Neso-, cyclo-, ino- and phyllosilicates. Eur J Mineral 32:101-119

Sheldrick GM (2008) XPREP, version 2008/2. Bruker-AXS, Madison, Wisconsin, USA

Takeda H, Donnay JDH (1966) Trioctahedral one-layer Micas. III. Crystal structure of a synthetic lithium fluor mica. Acta Cryst 20:638-646

Takeda H, Morosin B (1975) Comparison of observed and predicted structural parameters of mica at high temperature. Acta Cryst B $31: 2444-2452$

Tischendorf G (1999) The correlation between lithium and magnesium in trioctahedral micas: improved equations for $\mathrm{Li}_{2} \mathrm{O}$ estimation from $\mathrm{MgO}$ data. Mineral Mag 63:57-74

Toraya H, Iwai S, Marumo F, Daimon M, Kondo R (1976) The crystal structure of tetrasilicic potassium fluor mica, $\mathrm{KMg}_{2.5} \mathrm{Si}_{4} \mathrm{O}_{10} \mathrm{~F}_{2}$. Z Kristallogr 144:42-52

Toraya H, Iwai S, Marumo F, Nishikawa T, Hirao M (1978) The crystal structure of synthetic mica, $\mathrm{KMg}_{2.75} \mathrm{Si}_{3.5} \mathrm{Al}_{0.5} \mathrm{O}_{10} \mathrm{~F}_{2}$. Mineral J 9:210-220

Ventruti G, Zema M, Scordari F, Pedrazzi G (2008) Thermal behavior of a Ti-rich phlogopite from Mt. Vulture (Potenza, Italy): an in situ X-ray single-crystal diffraction study. Am Mineral 93:632-643

Wang A, Freeman JJ, Jolliff BL (2015) Understanding the Raman spectral features of phyllosilicates. J Raman Spectrosc 46:829-845

Weiss Z, Rieder M, Chmielová M, Krajíček J (1985) Geometry of the octahedral coordination in micas: a review of refined structures. Am Mineral 70:747-757

Weiss Z, Rieder M, Chmielová M (1992) Deformation of coordination polyhedra and their sheets in phyllosilicates. Eur J Mineral 4:665-682

Zema M, Ventruti G, Lacalamita M, Scordari F (2010) Kinetics of $\mathrm{Fe}$-oxidation/deprotonation process in Fe-rich phlogopite under isothermal conditions. Am Mineral 95:1458-1466

Publisher's Note Springer Nature remains neutral with regard to jurisdictional claims in published maps and institutional affiliations. 